\title{
Hubungan HbA1c dengan Lingkar Pinggang, Rasio Lingkar Pinggang- Tinggi Badan, Indeks Massa Tubuh, dan Lingkar Lengan Atas pada Remaja Perempuan Overweight/Obesitas
}

Febry Dwi Indrawati, Annang Giri Moelyo, Bambang Soebagyo

Bagian Ilmu Kesehatan Anak Fakultas Kedokteran Universitas Sebelas Maret/RSUD dr. Moewardi, Surakarta

Latar belakang. Obesitas memiliki risiko terhadap penyakit kardiovaskular dan metabolik. Lingkar pinggang (LP), rasio lingkar pinggang-tinggi badan (RLPTB), indeks massa tubuh (IMT), dan lingkar lengan atas (LiLA) merupakan indeks antropometrik untuk menentukan obesitas sentral dan berkaitan dengan kadar insulin. Pada orang dewasa, distribusi lemak di sekitar pinggang adalah prediktor yang valid dari kadar hemoglobin A1c (HbA1c). Pengukuran ini memiliki kelebihan dibandingkan dengan tes glukosa darah puasa dan toleransi glukosa oral karena mudah dan murah.

Tujuan. Untuk menentukan korelasi antara level HbA1c dengan lingkar pinggang, rasio lingkar pinggang-tinggi badan, indeks massa tubuh, dan lingkar lengan atas.

Metode. Penelitian potong lintang ini dilakukan di SMP 4 Surakarta, data diperoleh secara consecutive sampling. Siswi overweight dan obesitas yang memenuhi kriteria termasuk dalam penelitian ini. Subjek menjalani pengukuran LP, RLPTB, IMT, LiLA, dan tes darah untuk kadar HbA1c. Semua data dianalisis dengan menghitung uji korelasi dengan signifikan $<0,05$.

Hasil. Dua puluh sembilan siswi overweight/obesitas berpartisipasi dalam penelitian ini. HbA1c dan lingkar lengan atas memiliki korelasi positif dalam kategori sedang $(r=0,580 ; \mathrm{p}=0,001)$. HbA1c tidak berhubungan dengan LP $(r=0,044 ; \mathrm{p}=0,821), \mathrm{RLPTB}$ $(\mathrm{r}=0,060 ; \mathrm{p}=0,758)$, dan IMT $(=0,007 ; \mathrm{p}=0,971)$.

Kesimpulan. Lingkar lengan atas memiliki korelasi positif yang signifikan dengan kadar HbA1c pada remaja yang overweight dan obesitas. Sari Pediatri 2019;21(3):164-9

Kata kunci: HbA1c, obesitas, remaja, lingkar pinggang, rasio lingkar pinggang-tinggi badan, indeks massa tubuh, lingkar lengan atas

\section{The correlation of $\mathrm{HbA1} \mathrm{c}$ with waist circumference, waist-to-height ratio, body mass index, and mid-upper arm circumference in overweight/obese adolescent girls}

Febry Dwi Indrawati, Annang Giri Moelyo, Bambang Soebagyo

Background. Obesity has a risk of cardiovascular and metabolic disease. Waist circumference, waist-to-height ratio, body mass index, and mid-upper arm circumference are anthropometric indices for determining central obesity and have been associated with insulin levels. In adults, fat distribution around the waist is a valid predictor of hemoglobin A1c (HbA1c) levels. This measurement has advantages compared to fasting blood glucose and oral glucose tolerance tests, because it is simple and inexpensive.

Objective. To determine the correlation of HbA1c level with waist circumference, waist-to-height ratio, body mass index and midupper arm circumference.

Methods. This cross-sectional study was conducted in junior high school 4 Surakarta. The samples were obtained by consecutive sampling. Overweight and obese students who met the criteria were included in this study. All subjects underwent waist circumference, waist-to-height ratio, body mass index, mid-upper arm circumference measurements and blood tests for HbA1 levels. All data were analyzed by calculating the correlation test between independent variables and dependent variables with a significant of $<0.05$.

Results. Twenty-nine overweight/obese girl students participated in this study. HbA1c and mid-upper arm circumference had a positive correlation in the moderate category $(\mathrm{r}=0.580 ; \mathrm{p}=0.001)$. HbA1c was not found to be associated with waist circumference $(\mathrm{r}=0,044 ; \mathrm{p}=0.821)$, waist-to-height ratio( $\mathrm{r}=0.060 ; \mathrm{p}=0.758)$, and body mass index $(\mathrm{r}=0.007 ; \mathrm{p}=0.971)$.

Conclusion. Mid-upper arm circumference has significant positive correlation with HbA1c levels in overweight and obese adolescents. Sari Pediatri 2019;21(3):164-9

Key words: HbA1c, obese, adolescent, waist circumference, waist-to-height ratio, body mass index, mid-upper arm circumference

Alamat korespondensi: Febry Dwi Indrawati. Bagian Ilmu Kesehatan Anak Fakultas Kedokteran Universitas Sebelas Maret/RSUD dr. Moewardi Surakarta. Email: dr.febrydwi0312@gmail.com 


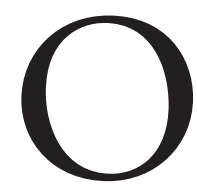
besitas merupakan masalah kesehatan yang jumlahnya meningkat di seluruh dunia. Badan kesehatan dunia WHO (World Health Organization) tahun 2015 menyatakan bahwa obesitas sudah menjadi wabah global. Obesitas didefinisikan sebagai suatu kelainan atau penyakit yang ditandai dengan penimbunan jaringan lemak tubuh secara berlebihan. ${ }^{1}$ Obesitas pada anak sampai saat ini masih merupakan masalah yang kompleks. Penyebabnya multifaktorial sehingga menyulitkan tata laksana. Obesitas pada anak berisiko tinggi akan berpotensi mengalami penyakit seperti diabetes melitus (DM). ${ }^{2}$ Sejak tahun 1990, kejadian obesitas pada anak usia 6-15 tahun meningkat 3 kali lipat, dari 5\% tahun 1990 menjadi 16\% tahun 2001. ${ }^{3}$ Pada skala nasional, masalah kegemukan anak umur 6 - 12 tahun masih tinggi, yaitu $9,2 \%$ atau masih di atas 5\%. Jawa Tengah termasuk salah satu dari 11 provinsi yang memiliki prevalensi kegemukan di atas prevalensi nasional. Prevalensi obesitas dari 170.699 anak usia 5 - 15 tahun di Indonesia adalah 8,3\%. ${ }^{4}$

Hemoglobin A1c (HbA1c) merupakan baku emas untuk penilaian homeostasis glukosa. HbA1c adalah integrasi variasi glukosa darah puasa dan postprandial selama periode 3 bulan. ${ }^{5}$ Pengukuran $\mathrm{HbA1c}$ penting bagi penderita diabetes sebab semakin tinggi HbAlc, semakin tinggi risiko untuk mengalami komplikasi terkait diabetes. Diabetes melitus merupakan penyakit metabolik yang ditandai dengan timbulnya hiperglikemia akibat gangguan sekresi insulin, dan atau peningkatan resistensi insulin seluler. ${ }^{6}$ Pada anak dan remaja obesitas, kelebihan lemak kemungkinan besar terakumulasi di regio abdomen. Obesitas sentral secara patofisiologis terkait dengan resistensi insulin atau penurunan sensitivitas insulin yang merupakan risiko terjadinya toleransi glukosa terganggu. ${ }^{7}$ Indikator antropometri perlu diteliti untuk menilai lemak viseral seperti indeks massa tubuh (IMT), lingkar pinggang (LP), rasio lingkar pinggang-tinggi badan (RLPTB), dan lingkar lengan atas (LiLA).

Pada usia pubertas terjadi perubahan hormonal utama meliputi peningkatan dua kali lipat dalam sekresi hormon pertumbuhan dan peningkatan steroid seks cenderung untuk mendorong ketidakpekaan terhadap insulin selama masa pubertas. ${ }^{8}$ Remaja perempuan dipilih karena metabolisme glukosanya sangat dipengaruhi oleh status pubertas. Selain itu, lebih mudah membedakan remaja perempuan yang sudah melewati masa pubertas dengan status menstruasinya. Sejauh ini belum didapat penelitian yang menyatakan jenis indikator antropometri terbaik berhubungan dengan $\mathrm{HbA1c}$, terutama pada usia pubertas. Berdasarkan keterangan di atas peneliti tertarik untuk mengetahui dan menganalisis hubungan $\mathrm{HbA1c}$ dengan lingkar pinggang, rasio lingkar pinggang tinggi badan, indeks massa tubuh, dan lingkar lengan atas pada remaja perempuan obesitas.

\section{Metode}

Penelitian potong lintang di SMP 4 Surakarta antara bulan Oktober 2018 - Desember 2018. Subjek penelitian adalah semua siswi di SMP 4 kelas 2 dan 3. Cara pengambilan sampel dengan cara consecutive sampling. Kriteria inklusi adalah semua siswi perempuan di SMP 4 kelas 2 dan 3, bersedia menandatangani surat persetujuan dari orang tua atau wali, skor L-MMPI (Lie-scale Minnesota Multiphasic Personality Inventory) pada jawaban "tidak" $\leq 10$. Kriteria eksklusi meliputi siswi yang mengonsumsi obat-obatan jangka panjang (>2 minggu), siswi yang sedang sakit kronis (asma, penyakit jantung, penyakit paru, penyakit ginjal, dll)

Diagnosis overweight/obesitas dengan pemeriksaan antropometri menggunakan IMT. Klasifikasi overweight $\geq$ persentil ke- 85 dan obesitas $\geq$ persentil ke-95. Pada sampel juga dilakukan pengukuran LP, RLPTB, dan LiLA. Pemeriksaan HbA1c diukur dengan alat Bio-Rad Variant II Turbo 2.0 bersertifikat NGSP di laboratorium Prodia. Analisis statistik hubungan HbA1c dengan LP, RLPTB, IMT, dan liLA dengan uji Pearson Product Moment untuk distribusi data normal dan uji Spearman Rank bila distribusi data tidak normal. Hasil uji statistik dinilai signifikan bila nilai $\mathrm{p}<0,05$. Penelitian ini telah mendapatkan persetujuan dari Komite Etik Penelitian Kesehatan RSUD dr. Moewardi-FK UNS Surakarta.

\section{Hasil}

Penelitian ini dilakukan pada 29 siswi di SMP 4 kelas 2 dan 3 Surakarta antara bulan Oktober 2018 Desember 2018. Usia paling banyak pada penelitian ini adalah 13-14 tahun. Suku paling banyak merupakan suku Jawa. Karakteristik dasar subjek penelitian dan deskripsi data tertera pada Tabel 1 dan 2 . 
Febry Dwi Indrawati dkk: Hubungan HbA1c dengan lingkar pinggang, rasio lingkar pinggang-tinggi badan, indeks massa tubuh, dan lingkar lengan atas pada remaja perempuan overweight/obesitas

Tabel 1. Karakteristik dasar subjek penelitian

\begin{tabular}{lcccc}
\hline Variabel & Frekuensi & Persentase & $\mathrm{r}$ & $\mathrm{p}$ \\
\hline Usia (tahun) & & & 0,077 & $0,692^{1}$ \\
$13-14$ & 18 & 62,1 & & \\
$>14-15$ & 11 & 37,9 & & \\
Suku & & & 0,271 & $0,371^{2}$ \\
$\quad$ Cina & 2 & 6,9 & & \\
Jawa & 26 & 89,7 & & \\
Manado & 1 & 3,4 & & \\
Riwayat DM & & & 0,203 & $0,291^{2}$ \\
Ada & 6 & 20,7 & & \\
Tidak ada & 23 & 79,3 & & \\
\hline
\end{tabular}

Keterangan : ${ }^{1}$ Uji Spearman rank (data Ordinal), ${ }^{2}$ Uji Eta (Data Nominal)

Tabel 2. Deskripsi data penelitian

\begin{tabular}{lccccc}
\hline Variabel & Minimum & Maksimum & Rerata & SD & $\mathrm{p}$ \\
\hline LP & 74,00 & 112,50 & 86,98 & 9,14 & 0,107 \\
RLPTB & 0,47 & 0,71 & 0,56 & 0,06 & 0,110 \\
LiLA & 26,50 & 39,00 & 31,06 & 2,99 & 0,397 \\
IMT & 24,30 & 37,38 & $28,55^{*}$ & 3,79 & 0,001 \\
HbAlc & 4,80 & 5,90 & 5,38 & 0,32 & 0,120 \\
\hline
\end{tabular}

*median

Tabel 3. Hubungan HbA1c dengan LP, RLPTB, LiLA, IMT

\begin{tabular}{lccc}
\hline Variabel & Rerata \pm SD & $\mathrm{r}$ & $\mathrm{p}$ \\
\hline HbA1c & $5,38+0,32$ & & \\
LP & $86,98+9,14$ & 0,044 & 0,821 \\
RLPTB & $0,56 \pm 0,06$ & 0,060 & 0,758 \\
LiLA & $31,06 \pm 2,99$ & 0,580 & 0,001 \\
IMT & $28,55 \pm 3,79$ & 0,007 & 0,971 \\
\hline
\end{tabular}

Pada Tabel 1 di atas menunjukkan bahwa pada subjek penelitian tidak didapatkan hubungan yang signifikan antara usia, suku dan riwayat DM dengan kadar HbA1c. Berdasarkan Tabel 2 diketahui bahwa LP, RLPTB, LiLA dan HbAlc berdasarkan hasil uji normalitas Shapiro wilk didapatkan distribusi data normal ( $\mathrm{p}=0,107 ; \mathrm{p}=0,110 ; \mathrm{p}=0,397 ; \mathrm{p}=0,120)$. IMT berdasarkan uji normalitas Shapiro wilk mendapatkan nilai $\mathrm{p}=0,001(\mathrm{p}<0,05)$ yang berarti bahwa distribusi data IMT tidak normal. Hubungan HbA1c dengan LP, RLPTB, IMT dan LiLA tertera pada Tabel 3 sebagai berikut.
Hasil uji korelasi product moment pada Tabel 3 diketahui bahwa tidak ada hubungan $\mathrm{HbAlc}$ dengan LP ( $\mathrm{p}=0,821)$ dan RLPTB ( $\mathrm{p}=0,758)$. Berdasarkan hasil uji korelasi Spearman rank pada Tabel 3 diketahui bahwa tidak ada hubungan HbA1c dengan IMT $(\mathrm{p}=0,971)$. Hasil uji korelasi product moment pada Tabel 3 diketahui bahwa hubungan HbA1c dengan LiLA mendapatkan nilai $r=0,580$ yang berarti bahwa terdapat hubungan yang positif antara kadar HbAlc dengan LiLA, kekuatan hubungan dalam kategori sedang. Nilai $\mathrm{p}=0,001(\mathrm{p}<0,05)$ yang berarti bahwa hubungan antara kadar HbA1c dengan LiLAsignifikan secara statistik. Berdasarkan kurva linier pada Gambar 1 didapatkan nilai koefisien regresi pada variabel HbA1c dengan LiLAsebesar 0,067. Hal ini berarti bahwa apabila ada peningkatan ukuran LiLA sebesar 1 angka maka akan meningkatkan kadar $\mathrm{HbAl}$ c sebesar 0,067 .

\section{Pembahasan}

Hasil penelitian ini menunjukkan bahwa karakteristik 


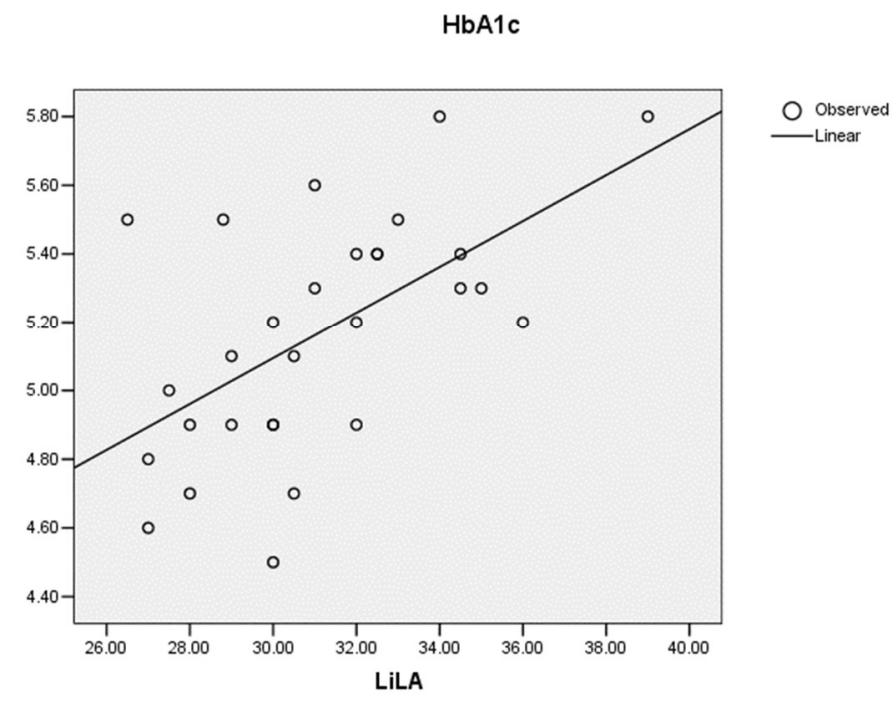

Gambar 1. Kurva linier hubungan antara kadar HbA1c dengan LiLA

subjek penelitian terbanyak pada usia 13-14 tahun dengan dominasi Suku Jawa dan 20,7 \% di antara mempunyai keluarga dengan riwayat DM. Obesitas sentral secara patofisiologis terkait dengan resistensi insulin atau penurunan sensitifitas insulin yang merupakan risiko terjadinya toleransi glukosa terganggu. Penurunan sensitivitas insulin perifer ini terbukti berhubungan dengan lemak viseral. ${ }^{9}$ Pada obesitas sentral terjadi peningkatan sitokin terutama TNF- $\alpha$ dan IL-6 yang berakibat pada meningkatnya lipolisis dan pelepasan asam lemak bebas yang akan ditimbun di hati, otot skelet, dan sel $\beta$ pankreas yang pada akhirnya menyebabkan keadaan hiperglikemia dan hiperinsulinemia. Keadaan hiperinsulinemia pada obesitas sentral ini menunjukkan penurunan sensitivitas insulin atau resistensi insulin. ${ }^{10}$

Penurunan sensitivitas insulin perifer ini juga terbukti berhubungan dengan lemak viseral. Resistensi insulin dapat meningkatkan kadar glukosa darah sehingga menyebabkan kegagalan pengambilan glukosa oleh otot. Seiring dengan peningkatan kadar glukosa darah maka kadar HbA1c juga meningkat sebab terdapat hubungan langsung antara $\mathrm{HbA} 1 \mathrm{c}$ dan rata-rata glukosa darah. Hubungan tersebut terjadi karena eritrosit terus-menerus terglikosilasi selama 120 hari masa hidupnya dan laju pembentukan glikohemoglobin setara dengan konsentrasi glukosa darah. Kadar HbAlc yang tinggi akan ditemukan pada individu dengan kadar glukosa yang tinggi. ${ }^{11}$ Rerata kadar HbA1c adalah 5,38 \%. Responden yang mengalami obesitas kemungkinan masih dalam fase awal gangguan resistensi insulin atau belum terdapat resistensi insulin. Tambahan pula, responden berada pada usia pubertas sehingga bila diuji dengan $\mathrm{HbAlc}$ masih menunjukkan di bawah ambang batas kategori diabetes. Hal tersebut menjadi salah satu penyebab didapatkan hasil penelitian tidak bermakna.

Pengukuran LP dapat digunakan untuk memprediksi adanya timbunan lemak pada daerah intra abdomen/obesitas sentral, yang merupakan salah satu penanda risiko penyakit diabetes. ${ }^{12}$ Hasil penelitian ini menunjukkan bahwa tidak ada hubungan antara HbA1c dengan LP. Hal ini sejalan dengan penelitian oleh Ellysa dkk ${ }^{13}$ yang melaporkan HbA1c dengan LP memiliki hubungan yang sangat lemah. Namun menurut Hasanuddin $\mathrm{dkk}^{14}$ pada penelitian anak SMA usia 15-18 tahun, terdapat perbedaan yang bermakna antara $\mathrm{HbA1c}$ dengan IMT dan LP pada overweight, obesitas dan normoweight. Studi lain mengatakan LP berkorelasi dengan HbA1c, tetapi RLPTB dan IMT tidak berkorelasi dengan HbA1c. ${ }^{15}$ Lingkar pinggang tidak memperhitungkan ketinggian individu, pengukuran ini memiliki nilai terbatas untuk digunakan pada populasi dengan varietas tinggi, seperti Indonesia.

Kadar HbA1c dengan RLPTB tidak didapatkan hubungan bermakna. Penelitian lain hanya dilakukan oleh Ellysa $\mathrm{dkk}^{13}$ yang melaporkan RLPTB dengan kadar HbA1c secara bermakna mempunyai hubungan positif lemah. Freedman $\mathrm{dkk}^{16}$ melaporkan bahwa 
Febry Dwi Indrawati dkk: Hubungan HbA1c dengan lingkar pinggang, rasio lingkar pinggang-tinggi badan, indeks massa tubuh, dan lingkar lengan atas pada remaja perempuan overweight/obesitas

pengukuran RLPTB dapat mengidentifikasi risiko kardiometabolik lebih tinggi. Pemeriksaan ini lebih disukai karena tidak membutuhkan cutt-off jenis kelamin dan usia. Pada penelitian ini, HbA1c dengan IMT juga tidak didapatkan hubungan bermakna. Hasanuddin $\mathrm{dkk}^{14}$ melaporkan bahwa terdapat perbedaan bermakna antara IMT dan kadar HbA1c, tetapi pada penelitian ini tidak melihat korelasi antara keduanya. Hasil penelitian ini sejalan dengan Eldeirawi $\mathrm{dkk}^{17}$ yang melaporkan bahwa IMT tidak berbeda terharap kadar HbA1c.

Pengukuran LiLA terbilang mudah, murah, cepat, dan praktis. Pengukuran LiLA telah digunakan untuk menilai kondisi kekurangan gizi. Namun, saat ini pengukuran LiLA memiliki akurasi tinggi untuk mengidentifikasi obesitas. Data mengenai pengukuran LILA pada anak menurut WHO adalah apabila $>14 \mathrm{~cm}(>85 \%)$ dikatakan normal dan $<12,5$ $\mathrm{cm}(76 \%)$ dikatakan malnutrisi. ${ }^{18}$ Penggunaan LiLA saat ini hanya dipakai pada usia 1-5 tahun karena pertumbuhan LiLA pada usia tersebut cenderung statis dengan standar deviasi yang sempit. Sementara jika usia di atas 5 tahun, apalagi pada usia pubertas yang berbeda antara laki-laki dan perempuan, akan membuat nilai standar deviasi yang makin lebar.

Pada penelitian ini didapatkan hubungan $\mathrm{HbA1c}$ dengan LiLA dalam kategori sedang yang bermakna secara bermakna. Hal ini sesuai dengan penelitian oleh Craig $\mathrm{dkk}^{18}$ yang melaporkan nilai ROC-AUC LiLA antara 0,90 dan 0,97 untuk memprediksi overweight/ obese pada anak kulit hitam Afrika Selatan usia 5-14 tahun. Jaiwal $\mathrm{dkk}^{19}$ juga melaporkan penelitian yang sama dengan pada anak India usia 5-14 tahun dengan hasil AUC 0,92-0,98. Lu dkk ${ }^{20}$ juga melaporkan hasil AUC 0,93 dan 0,98 pada anak Han usia 7-12 tahun. Pada penelitian ini hanya didapakan hubungan antara LiLA dengan HBA1c sehingga tidak dilakukan analisis multivariat. Penelitian ini menunjukkan bahwa LiLA memiliki potensi sebagai alat skrining untuk mengidentifikasi remaja yang membutuhkan penilaian lebih lanjut manajemen klinis dari obesitas. Indonesia belum terdapat penelitian yang menggunakan LiLA untuk memprediksi overweight/obesitas dengan HbA1c pada anak di atas 5 tahun sehingga belum ada data yang dapat dijadikan pembanding. Penelitian ini juga tidak bisa menggeneralisasi pada semua usia pubertas, dan belum ada penelitian lain di luar usia pubertas yang kami teliti sehingga dalam pengaplikasiannya harus digunakan secara hati-hati.

\section{Kesimpulan}

Lingkar lengan atas memiliki korelasi positif yang signifikan dengan kadar $\mathrm{HbAlc}$ pada remaja yang overweight dan obesitas.

\section{Daftar pustaka}

1. Sjarif DR. Obesitas anak dan remaja. Dalam: Sjarif DR, Lestari ED, Mexitalia M, Nasar SS, penyunting. Buku ajar nutrisi pediatrik dan penyakit metabolik. Edisi I revisi. Badan Penerbit IDAI;2014.h.236-47.

2. Julia M, Utari A, Nurrochmah, Moelyo AG. Konsensus Nasional Pengelolaan Diabetes Melitus tipe 2. Jakarta: Ikatan Dokter Anak Indonesia;2015.h.1-30.

3. Craig ME. Hattersley A. Donaghue KC. Definition, epidemiology and classification of diabetes in children and adolescents, ISPAD Clinical Practice Consensus Guidelines 2009 Compendium, International Society for Pediatric and Adolescent Diabetes. Pediatr Diabetes 2009;10:3-12.

4. Depkes. Riset Kesehatan Dasar 2010. Jakarta: Badan Penelitian dan Pengembangan Kesehatan; 2010.

5. International Expert Committee. Report on the role of the $\mathrm{A} 1 \mathrm{C}$ assay in the diagnosis of diabetes. Diabetes Care 2009;32:1327-34.

6. Anila Chadha, MD, Malcolm S. Schwartz. Type 2 diabetes mellitus in childhood: obesity and insulin resistance. JAOA 2008;108:518-24.

7. Gungor, Hannon T, Libman I. Type 2 Diabetes mellitus in youth: the complete picture to date. Pediatr Clin N Am 2005;52:1579-61.

8. Tfayli Hala, Arslanian S. The challenge of adolescence: hormonal changes and sensitivity to insulin. Diabetes Voice 2007;52:28-30.

9. Savage DB, Petersen KF, Shulman GI. Mechanism of insulin resistance in humans and possible links with inflammation. Hypertension 2009; 45:828-33.

10. Freedman DS, Serdula MK, Srinivasan SR, Berenson GS. Relation of circumferences and skinfold thickness to lipid and insulin concentrations inchildren and adolescents: The Bogalusa Heart Study. Am J Clin Nutr 1999;69:308-17.

11. Wijaya A, Aditiawati, Saleh I. Akurasi pemeriksaan HbA1c dalam mendeteksi gangguan toleransi glukosa pada anak dan remaja obes dengan riwayat orang tua DM tipe 2. Sari Pediatri 2015;17:17-20.

12. Hirschler V, Aranda C, Calcagno ML, Maccalini G, Jadzinsky M. Can waist circumference identify children 
Febry Dwi Indrawati dkk: Hubungan HbA1c dengan lingkar pinggang, rasio lingkar pinggang-tinggi badan, indeks massa tubuh, dan lingkar lengan atas pada remaja perempuan overweight/obesitas

with the metabolic syndrome? Arch Pediatr Adolesc Med 2005;159:750-4.

13. Ellysa S, Nuraini N, Julia M. Glycated hemoglobin HbA1c, waist circumference and waist to height ratio in overweight and obese adolescent. Paediatr Indones 2017;57:57-62.

14. Hasanuddin, Patellongi I, Idris I, Rosdiana. HbA1c levels in adolescent obesity, overweight and normoweight catholic high school eagles in Makassar Rajawali. Media Neliti 2011;1:257-61.

15. Nasir BM, Aziz AA, Abdullah MR, Norhayati MN. Waist height ratio compared to body mass index and waist circumference in relation to glycemic control in Malay type 2 diabetes mellitus patients, Hospital Universiti Sains Malaysia. Intl J Collab Res Internal Med Public Health 2012;4:406-15.

16. Freedman D, Kahn H, Mei Z, Grummer L, Dietz W, Srinivasan S, dkk. Relation of body mass index and waist-toheight ratio to cardiovascular disease risk factors in children and adolescents: the Bogalusa Heart Study. Am J Clin Nutr 2007;86:33-40.

17. Eldeirawi K, Lipton RB. Predictors of hemoglobin A1c in a national sample of nondiabetic children: the Third National Health and Nutrition Examination Survey, 1988-1994. Am J Epidemiol 2003;157:624-32.

18. Craig E, Bland R, Ndirangu J, Reilly J. Use of mid-upper arm circumference for determining overweight and overfatness in children and adolescents. Arch Dis Child 2014;0:1-4.

19. Jaswal M, Bansal R, Agarwal A. Role of mid-upper arm circumference for determining overweight and obesity in children and adolescents. J CDiag Res 2017;11:1-8.

20. Lu Q, Wang R, Lou D, Ma C, Liu X, Yin F. Mid-upperarm circumference and arm-to-height ratio in evaluation of overweight and obesity in Han children. Pediatr Neonatol 2014;55:14-19. 